\title{
«THE TINY LIBRARY» (1877-1880) I. FRANKO'S AS ONE AN EXAMPLE OF A SUCCESSFUL COMMUNICATIVE INTERACTION IN A CULTURAL CONTEXT
}

\section{SYROTA Liliia,}

$\mathrm{PhD}$ (Filology),

Faculty of culture and art, Lviv National University Ivan Franko, 18 Valova str., Lviv, 79008, Ukraine e-mail: liljasyrota@yahoo.com.

The article is devoted to the study of the publishing activity of Ivan Franko in the second half of the 1870's, in particular the book series "The Tiny Library». A books I. Franko's became a research object. His epistolary heritage was analyzed. The article deals on the processes of formation and functioning of the book series "The Tiny Library" in XIX century. The article talks about the stages of work in the series, such as the translation of texts, the search for sources of funding, change of the thematic, as well as reasons of the closing the series. Among the basic methods of research is analise of the historical and bibliographical sources, monographs, articles and letters, and so on. It gave an opportunity to find the necessary information in letters to $M$. Drahomanov, O. Roshkevych, $M$. Pavlyk, information about the aktivities I. Franko's in general which is located in on-line. In the article defined basic directions of publishing activities of Ivan Franko during 1877-1880 years.

Key words: Ivan Franko, book series «The Tiny Library», epistolary heritage, thematic, translation, funding, 1877-1880th.

\section{«ДРІБНА БІБЛІОТЕКА» І. ФРАНКА (1877-1880): ПРИКЛАД УСПІШНОї КОМУНІКАТИВНОЇ ВЗАЄМОДІЇ 3 КУЛЬТУРНИМ КОНТЕКСТОМ}

Статтю присвячено вивченню видавничої діяльності Івана Франка у другій половині 1870-х рр., зокрела книжковій серї “Дрібна бібліотека». Об”єктол дослідження стали книги Івана Франка. Проаналізовано його епістолярну спадщину. У статті розглядаються процеси форлування та особливості функиіонування книжкової серї "Дрібна бібліотека» у XIX столітті. Говориться про етапи роботи в серї, такі як переклад текстів, пошук джерел фінансування, зліна телатики, а також причини закриття серії. Серед основних методів дослідження-аналіз історико-бібліографічних джерел, монографій, статей та листів тощо. Він дав можливість виокрелити необхідну інфорлацію у листах письленника до М. Драголанова, О. Рошкевич, М. Павлика, відомості про активність I. Франка в иілому, які знаходяться в режилі он-лайн. У статті визначенои основні напряли видавничої діяльності І. Франка упродовж 1877-1880 років.

Ключові слова: Іван Франко, книжкова серія "Дрібна бібліотека», епістолярна спадщина, те матика, переклад, фінансування, 1877-1880.

$\mathbf{I}$

ntroduction. Ivan Franko has a special place in the publishing process of the second half of the nineteenth century, because he was engaged in publishing books, cared about nationwide culture of a scientific, educational and literary book. The writer in his versatile activities was closely connected with the Lviv publishing house and the book, in particular, with its creation, functioning, distribution. Ivan Franko's wide interest in Ukrainian book and publishingis manifested himself in his artistic, scientific works and epistolary.

Today the publishing activity his writter's and his views on the development of Ukrainian book still require comprehensive and systematic research. Epistolary heritage Franko's, which contains valuable information about the unknow moments in its life and work, deserves .particular attention of a researcher. Role and place of I. Franko in (C) Syrota L., 2018 
Ukrainian culture are discussed today on the pages of a scientific journals and collections $[1 ; 23]$. The political and national realities of the second half of the 1880's should be studied from the point of view of our time.

The purpose of the article is to confirm the significance of Ivan Franko's figure in the Ukrainian publishing process of the second half of the nineteenth century, also his contribution to the development of translation and education in Halychyna. The goal set determines the following main tasks, namely:

1) to trace the writer's thoughts about the importance of expanding the Ukrainian cultural space, the elimination of the status of provincialism, and the approximation of the Ukrainian book to the European intellectual and cultural level;

2) to find out the reasons for the short duration in publishing projects, to examine the context of their functioning;

3) to study the publishing contacts of Ivan Franko.

Ivan Franko is a well-known publisher of many book projects. Our article is devoted to the first publishing series of this writer - «The Tiny Library», which testified about the targeting of the Ukrainian publishing houses of Halychyna to the printing of books for the Ukrainian intelligentsia, burghers and peasants.

Many studies have been published about the publishing activity of Ivan Franko, in particular, it's studies by B. Yakymovych, O. Dei and other [2; 21-22], but there are no separate scientific researches about the peculiarities of the formation and publication of the first book series by I. Franko "The Tiny Library». Let us turn to the epistolarium, to the book preface and other works of I. Franko to study all stages of the Ukrainian publishing project «The Tiny Library».

Research methods. The thematic-typological method allowed to select and logically to group information placed in the letters of Ivan Franko. «The Tiny Library» is analyzed in various aspects - thematic, translated, economic, and political. The chronological method had contribute to the placement of research results according to years of printing of parts of the book series, that is, from the beginning of the edition of the book series until the time of its completion.

The problem analysis method allowed to made conclusions about economic and political dependence of a part of the publishing products, about strong influence a European Tastes on the Reading of the Ukrainians. In general, the book series is investigated on the basis of the principles of impartiality, objectivity, historicism. The complex analytical, bibliographic, descriptive, genre-type unbiased methods of studying a epistolary and publications of Ivan Franko in the 1870's were used.

Results and discussion. "The Tiny Library» series, thanks to the professionalism in the selection of works and a high culture of the publication, provided the Ukrainian reader with the latest in the world of artistic, educational and scientific literature. I. Franko wrote that the "The Tiny Library» should primarily educate the young Ukrainian intelligentsia, promote its education [18]. Another purpose of the publication is «to woke a more significant movement in a province where little are in our publish still» [7].

From the letter to Drahomanov we learn that the idea of publishing a literary series arose in 1876 and delays in its appearance were associated with funding problems [3]. The initiator of the series was Ivan Beley, student of Lviv University [17, p. 249]. Ivan Franko supported him and actively participated in the implementation of this project, since the newspaper "Civic Friend», in which I. Franko worked, was closed, and M. Pavlyk, as co-editor, left Halychyna [20], and then was imprisoned.

In his book "The Essay on the History of Ukrainian-Russian Literature until 1890" (1910), Ivan Franko noted that the series began to emerge at the beginning of 1877 [17, p. 249]. About it Franko was also written by on April 21, 1877 in letter to Olga Roshkevych. He sended a works for translate to O. Roshkevych [10]. That is, we can set a more specific date for the beginning of the series release. 
In a letter to M. Drahomanov from February 6, 1877, I. Franko first wrote about his intentions to work on the new series. From this letter we learn that the begined idea was to unite under the common title only the novelties of foreign literature: «I have decided to publish a library of the most famous abroad novels and stories, translated into ours. This idea has risen up in me last year, I made a correspondence with some people and everyone encouraged me to that. Now I have the opportunity to find ... money, zlotyi to 500, to which I added a my scholarship of 110, will be 600 zlotyi» [3]. From the text of the letter, we see that the extent of I. Franko's participation in the creation of this publishing project was significant: he was its main organizer and became its sponsor.

The work on the series began before the arrest of Ivan Franko in July 1877 [17, p. 249]. In the middle of summer of 1878 Ivan Franko wrote that books of the series entitled «The Tiny Library» is already in Lviv. In particular, we read: "... Here are the Christians who publish «The Tiny Library», from which I send two notebooks» [14].

During the period 1877-1880 14 issues came in the series and one issue was not numbered, that is, together 15 books. The purpose of the project was to create a universal book series, which the latest works on various fields of a activity would include. In her, according to the writer's plan, literary-artistic and scientific works were to dominate. This series was published not only for educational but also for scientific purposes. «It was only a year before publishing "The Tiny Library», we had the idea to gradually print in it, besides to the of a dominant realistic trend, besides to examples of newer poetry with a social, scientific and political basis, mainly a number of scientific articles that would have had an accessible form of content, and they would systematically present all the main areas of modern human knowledge», wrote I. Franko [18].

I. Franko worked on the publication of the works in "The Tiny Library" at a time when there was no national unity among the figures in Halychyna, which led to sharp discussions in the political newspapers «Pravda» («The Truth»), «Druh» («The Friend») and others. In order to ensure social stability in the region («... creativing a objective, calm and non-fanatical thought about doing business» [3]), he sought to broaden and more objectively inform the readers about world political and aesthetic achievements by printing the works in a separate editions, without tying their authors to the periodical bodies of certain parties or organizations.

I. Franko, I. Belei and M. Pavlyk had to take care of the series "The Tiny Library», in particular to search for new texts and to deal questions with their publication and distribution. I. Franko wrote that they were trying to «slowly, shift» their activities «in other direction" - and this could easily be done in such a publishing house that I spoke about. It will unite us three in this business, in the basis of interest of each of us there will be a need to work over the books making as soon as possible, to find the buyers as possible and to conduct the accounts as accurately as possible, and in this way we will avoid a disagreement, various thefts and quarrels» [3].

However, at the same time I. Franko understood that in the Ukrainian book market there is a lack not only for the newest artistic, but also for the scientific literature and this lack must be filled. Therefore, in 1877, he had another plan - to publish a scientific series: "I still think that it would be better: to offer a small library of a beletristic for the broader audience in Halychyna, and for a more small circle we will print the best scientific works and on the this basis then we will turn to the print of a popular science editions..." [3].

I. Franko could not realize these two projects in the those scales which he originally conceived. The final result was the appearance of «The Tiny Library». The title of the series of a books was very eloquent, considering the fact that its various themes were always oriented to the broad masses. The writer saw his main task in a formation and education of a nationally conscious people. Therefore, he chose the print of books as the most effective tool for the realization of their far-sighted intentions. The title of the 
series - «The Tiny Library» - underlined her apolitical, broad purpose, available and unscientific content of a works.

In a letter to Olga Roshkevych from April 21, 1877, I. Franko wrote about the importance of translating the novel «Prey» by Emile Zola («La curee», 1871). It is the second novel in Émile Zola's monumental twenty-volume series «Rougon-Macquart» [10]. From this letter we learn that the writer sent a translated dictionary to I. Belei for the interpretation of some parts from the seventh volume «Trap» ( L'Assommoir» (1877)). I. Franko gave the name «The Sledgehammer» to the Ukrainian translation. For both translators he specified the term of translation - before the start of summer vacations, that is, until June. However, I. Belei did not translate the novel on time.

In a letter to O. Roshkevych of September 22, 1877, I. Franko asks her to send to him the work "Essays from the history of work» Dmitryi Pisarev's in the Polish language, two novels of Emil Zola: one of them - «The Fortune of the Rougons» («La Fortune des Rougon»), another in Russian - «The Conquest of Plassans» («La Conquête de Plassans»). The Ukrainian writer studied these creative works and himself selected them out for the "The Tiny Library» series, worked closely with translators. Series of the books «The Tiny Library» was appropriate to the current trends and news in the world book market and it became successful.

I. Franko did not renounce his intention to publish E. Zola's novel «Prey" in Ukrainian, despite the fact that the translator delayed with his interpretation. In a letter dated the beginning of March 1878 he reminded O. Roshkevych about the translation, in particular, asked her whether she had already translated this work [11]. From this letter we learn that there was another reason for the delay of the appearance books in the series. On March 5, 1878, I. Franko was released from prison (from the time of his arrest until his release from prison was 9 months) [11], and he not immediately continued a work with own book series. In order to improve his financial situation, he and M. Pavlyk were forced to work at night to publish a new newspaper "Civic Friend", the first issue of which was to be released in April [13]. There were only 2 numbers that were confiscated.

Ivan Franko, in letters to his correspondents, never specified the dates for publishing the volumes of the "The Tiny Library», explaining that "he still has nothing to work with" that this will happen when «implementation of the plan will move forward" [13]. In April 1878, he asks O. Roshkevych: «Translate Zola and send. If I can find «L'Assommoir», then I will send with you a new novel «Nabob» Dode's Doudet too, which is said to be good» [13]. I also find out that O. Roshkevych wanted to translate the first and second books of E. Zola from the epic «Rougon-Macquart». In addition, it is known that the novel by E. Zola «Trap» was translation under the name "The Sledgehammer» for the series «The Tiny Library" [16]. Ivan Franko and his friends also dreamed about starting a this series with works of well-known European writers, but due to different circumstances, the translation of "The Sledgehammer» was published only in 1879. The Ukrainian intelligentsia congratulated the translation of "The Sledgehammer» [16]. It is known that the first in the series came the book of the Russian writer Glib UspenskyiIvanov «War for freedom».

From the «Preface to the publishing house of "The Tiny Library", contained in the book «The Importance of Authority in Upbringing» M. Dobroliubov's, we were find out that I. Franko and other compilers and translators of the series could not to be "systematically get involved in work» on a one type of books. Books from the series were varied - a artistic, economic, political, pedagogical literature. «We devoted 3 books to the natural sciences ... This year we devoted only a one book to our economic science ... But we hope that in the coming year we will make up for it. We will pay more attention to working on texts on economics, not ignoring at the same time the natural sciences and other sciences. As soon as possible must start, in addition to the brochure Lavelle, also will issue a systematic textbook on the social economy ... In this book, volume 10, 
we want to present to our readers an analysis of one very important issue in pedagogy, namely, of the science of education", I. Franko wrote [18].

I. Franko attached great attention to the social and natural works and did not publish a historical works devoted to the life and activities of the princes, hetmans, generals, since, in his opinion, "history is so is often popularized" that new thinking does not arise in readers [7]. As Ivan Franko wrote, publishers of the time successfully continued business by printing socio-political literature. He gave an example: 300 copies of the work of G. Uspenskyi-Ivanov was sold during three weeks. The reason was «in a general temptation to the book novelties, which now began to appear in Halychyna» [4].

In 1879, I. Franko was called to the army, but did not stop publishing «The Tiny Library»: he was engaged in proofreading and translations [9. As of June 1879, 9 books were published in the series. At this time, he repeatedly wrote about changes in the series: "With "The Sledgehammer» and in general, with fiction, we will be to work later, forward it is necessary to skip something from scientific works. Ukrainians from Vienna raise money for the publication of one volume, and the creditors raise money also, namely, they want to print... Dobroliubov» [6]. In addition, educational literature was very in demand then. Therefore, in «The Tiny Library» I. Franko intended to issue «textbooks for school science, in order somebody from high school students or somebody from their academicians could lend them, and we could provide them with practical assistance» [6]. In particular, he planned to publish the «Encyclopedia of Natural Sciences» («Encyclopaedie der Naturwissenschaf»t) Edward Trevendt's and «Common History in Single Representations» («Allgemeine Geschichte in Einzeldarstellungen») Wilhelm Oncken's.

From a letter to M. Drahomanov from August 21, 1878, we will find out about other reasons for the publication of those and not other works in «The Tiny Library». He experiencing financial difficulties in work, and was guided by the demands of those strata of the population who could help the money and were interested in the appearance of certain books. Here's how I. Franko said: «... students collect money for Ivanov and Erk[man]-Shat[rian] - that means we were forced to leave the decision of a students in complete freedom ... I would like to place «The Bees» D. Pisarev's in the second notebook of «The Tin[y] Libr[ary]». Next year we could take Zola's «Rougon-Macquart», at least some parts. The first and second volumes are already almost made, "L'Assommoire» is translated. We can be quickly prepare «Abbé Mouret» also. You wrote that you could send a little money» [4].

The initiators of the publication of many works were representatives of the Ukrainian community in Vienna. This was evidenced by I. Franko himself: "The Ukrainians from Vienna sent ... translation of Haeckel's pamphlet on the science of development» [5]. Ivan Franko's activity was successful among youth in Halychyna, in particular the latest volume of "The Tiny Library" - a novella by the writer «The Lower Depths» was published without the consent of the author at the request of the public, and, as Ivan Franko wrote, he "made a strong impression on the readership. Polish working newspaper «Praca» («The Labor») begined (but did not finish) print the translation of this schort story I. Franko's [21].

The success into "The Tiny Library» series came slowly and the first signs of an in demand reades'sr for the were observed by the writer in 1879 [7] and they did not decrease in 1880. Publishing project «The Tiny Library» could develop successfully if there were not the financial difficulties and confiscations. In a letter to O. Roshkevych March 13, 1879 I. Franko said: «... the police confiscated my translation of Haeckel» [12]. In addition, he asks her to embark on the translation of the novel by E. Zola «The Trap» («L'Assommoir», 1877), whose was heavily criticized in France. Contrary to "our Ukrainians and the police,» the writer wanted to publish the this work in Lviv, but did not find support. This fact indicates that I. Franko was forced to take into account the 
public opinion, the aesthetic tastes of the readers [19]. He was financially dependent on them.

All volume series were printed in 500 copies, with the exception of E. Haeckel's work «Where and how did people evolved on the Earth?» (1000 copies) and E. Zola «The Sledgehammer» (200 copies). In a letter to M. Dragomanov I. Franko in 1887 wrote that he in "The Tiny Library» published the work of E. Haeckel «On the Origin of the Beasts» . This allows us to determine exactly which of the E. Heckel's studies was translated for the series. This is «Gastraea theorie» («Jenaische natur», 1874) [15, p. 253].

Several reasons for terminating the print of books in series «The Tiny Library» existed. This reasons can be clearly distinguished by comparing the functional purpose, unequal zone of a influence of works that belong to a books serie or published in newspaper. I. Franko was well aware of the ideological, organizational and informational advantages of the press («while working in newspapers, writing summaries there, reviews of scientific articles and so on, they can better develop their literary forces than during doing translations of an articles for «The Tin[y] Libr[ary]»... «The Tin[y] Libr[ary]» is was made up of larger works and they were rarely printed, becouse few specialisti were working on creating the books serie») [8].

«The Tiny Library» was discontinued not because of the lack of authors, works or translators, but because of the constant lack of funds. Works by H. T. Buckle, J. Lubbock, K. Marx, F. Engels, M. Chernyshevskyi, J. S. Mill, J. W. Draper, E. Zola, M. Pomyalovskyi, E. Engel, C. Vogt etc. were not published in this series [6]. Later I. Franko realized ideas in other publishing projects - in a magazines; in «The Library of the Most Famous Stories» that was published by the editorial staff of the newspaper «Dilo» («The Deed») (I. Belei is publisher) and in «The Ruthenian-Ukrainian Library» (Ye. Olesnitskyi is publisher).

Conclusions. The book series «The Tiny Library» undoubtedly had a significant impact on the public opinion of the second half of the 1870s and subsequent years, drawing the attention of both young people and representatives of the senior intelligentsia of Halychyna to the latest achievements of science and literature.

In the activity of I. Franko in the publishing sphere problems were, that could be solved only if close cooperation was with well-known representatives of Halychyna and emigration intellectuals. The high requirements from the editors, their persistent search activities ensured a high level of culture of the publication of all volumes of the series. The works published in «The Tiny Library» were known in European. Authors of the series were the well-known specialists in various fields of social and natural sciences - a historians, philosophers, economists, politicians. In the article priority attention was directed to translated novelties of fiction, scientific and educational literature. They gained wide resonance at Halychyna. The Ukrainian reader had a great opportunity to get acquainted with them in high quality translation.

1. Hrytsak, Ya. (2008), Between Semitism and Anti-Semitism: Ivan Franko and Jewish Question. In: Paradigm, Instytut Ukrajinoznavstva im. I. Krypjakevycha, Lviv, Ukrajina, available on: http://www.inst-ukr.lviv.ua/files/paradygma/50-91-gja.pdf (accessed 5.01.2018).

2. Dei, O. (1956), Revolutionalry edition I. Franko's 1878-1880th («The Tiny Library»). In: Investigating the creative work of Ivan Franko, Instytut suspil'nyh nauk, Kyiv, Ukraina.

3. Letter I. Franko's to M. Drahomanov (6 February 1877), available on: http://www.i-franko. name/uk/Corresp/1877/1877-02-06.html (accessed 11.01.2018).

4. Letter I. Franko's to M. Drahomanov (End of April 1878), available on: http://www.ifranko.name/uk/Corresp/1878/1878-04-mpd2.html (accessed 17.01.2018).

5. Letter I. Franko's to M. Drahomanov (21 Seprember 1878), available on: http://www.ifranko.name/uk/Corresp/1878/1878-08-21.html (accessed 14.01.2018).

6. Letter I. Franko's to M. Pavlyk (20 May - 6 June 1879), available on: http://www.i-franko. name/uk/Corresp/1879/1879-05-20.html (accessed 14.01.2018). 
7. Letter I. Franko's to M. Pavlyk (End of June 1879), available on: http://www.i-franko. name/uk/BioStudies/1881/EmilZola.html (accessed 14.01.2018).

8. Letter I. Franko's to M. Pavlyk (30 July 1879), available on: http://www.i-franko.name/ uk/Corresp/1879/1879-07-30.html (accessed 28.12.2017).

9. Letter I. Franko's to M. Pavlyk (Near 10 Oktober 1879), available on: http://www.i-franko. name/uk/Corresp/1879/1879-10-10.htm.( accessed 14.01.2018).

10. Letter I. Franko's to O. Roshkevych (21 April 1877), available on y: http://www.i-franko. name/uk/Corresp/1877/1877-04-21.html (accessed 11.01.2018).

11. Letter I. Franko's to O. Roshkevych (Beginning of March 1878), available on: http:// www.i-franko.name/uk/Corresp/1878/1878-03-omr.html (accessed 11.01.2018).

12. Letter I. Franko's to O. Roshkevych (End of April 1878), available on: http://www.ifranko.name/uk/Corresp/1878/1878-04-omr.html (accessed 14.01.2018).

13. Letter I. Franko's to O. Roshkevych (13 March 1879), available on: http://www.i-franko. name/uk/Corresp/1879/1879-03-13.html (accessed 28.12.2017).

14. Letter I. Franko's to O. Roshkevych (30 July 1878), available on: http://www.i-franko. name/uk/Corresp/1878/1878-07-30.html (accessed 12.01.2018).

15. The correspondence between Ivan Franko and Mykhailo Drahomanov (2006), Vydavnychyi tsentr LNU imeni Ivana Franka, Lviv, Ukraina.

16. Franko, I. Emil Zola. Biography, available on: http://www.i-franko.name/uk/ BioStudies/1881/EmilZola.html (accessed 14.01.2018).

17. Franko, I. (1910), Essay of history of Ukrainian-Ruthenian Literary till 1890th, UkrainskoVydavnycha Spilka, Lviv, Ukraina.

18. Franko, I. (1879), Preface from the publishing house "The Tiny Library», available on: http://www.i-franko.name/uk/Misc/1879/PerednjeSlovoVidVydavn.html (accessed 12.01.2018).

19. Franko, I. (1877), Novel E. Zola's «L'assommoir», available on: http://www.i-franko. name/uk/LitCriticism/1877/RomanEZoljaLassommoir.html (accessed 28.12.2017).

20. Franko, I. (1890), Curriculum vitae, available on: http://www.i-franko.name/uk/ Biography/CurriculumVitae1890.html (accessed 2.01.2018).

21. Yakymovych, B. (2006), Ivan Franko as publisher. A Bibliological and Source Study, Vydavnychyi tsentr LNU imeni Ivana Franka, Lviv, Ukraina.

22. Yakymovych, B. (1996), Book, enlightenment, nation, Instytut Ukrainoznavstva imeni Iwana Krypiakevycha, Lviv, Ukraina.

23. Jaremko, Ja. (2016), Ivan Franko's linguistic and political discourse and modern communication theory. In: Problems of the humanities. Series philology, Drohobyc'kyj derzhavnyj pedagogichnyj universytet imeni Ivana Franka, Drohobych, Ukrajina, available on: http://ddpu. drohobych.net/filol_gum/wp-content/uploads/2016/04/2016-03.pdf (accessed 12.02.2018).

1. Грицак Я. Між семітизмом й антисемітизмом: Іван Франко та єврейське питання [Електронний ресурс] / Ярослав Грицак // Парадигма: зб. наук. праць / гол. ред. Я. Ісаєвич; НАН України, Ін-т українознавства ім. І. Крип’якевича. - Львів: Ін-т українознавства ім. I. Крип'якевича, 2008. - Вип. 3. - С. 50-91 - Режим доступу : http://www.inst-ukr.lviv.ua/ files/paradygma/50-91-gja.pdf. - Дата доступу: 5.01.2018.

2. Дей О. Революційне видання Ів. Франка 1878-1880 рр. («Дрібна бібліотека») / О. Дей // Дослідження творчості Івана Франка / відп. ред.: І. П. Крип’якевич; АН УРСР, Ін-т сусп. наук. - Київ: Вид-во АН УРСР, 1956. - Вип. 1. - С. 34-67.

3. Лист І. Франка до М. Драгоманова (6 лютого 1877 р.) [Електронний ресурс] / Іван Франко. - Режим доступу : http://www.i-franko.name/uk/Corresp/1877/1877-02-06.html. - Дата доступу: 11.01.2018.

4. Лист І. Франка до М. Драгоманова (21 серпня 1878 р.) [Електронний ресурс] / Іван Франко. - Режим доступу : http://www.i-franko.name/uk/Corresp/1878/1878-08-21.html. Дата доступу: 5.01.2018.

5. Лист І. Франка до М. Драгоманова (кінець квітня 1878 р.) [Електронний ресурс] / Іван Франко. - Режим доступу : http://www.i-franko.name/uk/Corresp/1878/1878-04-mpd2.html. - Дата доступу: 17.01.2018.

6. Лист І. Франка до М. Павлика (20 травня - 6 червня 1879 р.) [Електронний ресурс] / Іван Франко. - Режим доступу : http://www.i-franko.name/uk/Corresp/1879/1879-05-20. html. - Дата доступу: 14.01.2018. 
7. Лист І. Франка до М. Павлика (кінець червня 1879 р.)[Електронний ресурс] / Іван Франко. - Режим доступу : http://www.i-franko.name/uk/BioStudies/1881/EmilZola.html. Дата доступу: 14.01.2018.

8. Лист І. Франка до М. Павлика (30 липня 1879 р.) [Електронний ресурс] / Іван Франко. - Режим доступу : http://www.i-franko.name/uk/Corresp/1879/1879-07-30.html. - Дата доступу: 28.12.2017.

9. Лист І. Франка до М. Павлика (біля 10 жовтня 1879 р.) [Електронний ресурс] / Іван Франко. - Режим доступу : http://www.i-franko.name/uk/Corresp/1879/1879-10-10.html. Дата доступу: 14.01.2018.

10. Лист І. Франка до О. Рошкевич (21 квітня 1877 р.) [Електронний ресурс] / Іван Франко. - Режим доступу : http://www.i-franko.name/uk/Corresp/1877/1877-04-21.html. - Дата доступу: 11.01.2018.

11. Лист І. Франка до О. Рошкевич (початок березня 1878 р.) [Електронний ресурс] / Іван Франко. - Режим доступу : http://www.i-franko.name/uk/Corresp/1878/1878-03-omr.html. Дата доступу: 11.01.2018.

12. Лист І. Франка до О. Рошкевич (13 березня 1879 р.) [Електронний ресурс] / Іван Франко. - Режим доступу : http://www.i-franko.name/uk/Corresp/1879/1879-03-13.html. - Дата доступу: 28.12.2017.

13. Лист І. Франка до О. Рошкевич (квітень 1878 р.) [Електронний ресурс] / Іван Франко. - Режим доступу : http://www.i-franko.name/uk/Corresp/1878/1878-04-omr.html. - Дата доступу: 14.01.2018.

14. Лист І. Франка до О. Рошкевич (30 липня 1878 р.) [Електронний ресурс] / Іван Франко. - Режим доступу : http://www.i-franko.name/uk/Corresp/1878/1878-07-30.html. - Дата доступу: 12.01.2018.

15. Листування Івана Франка та Михайла Драгоманова / Львів. нац. ун-т імені Івана Франка. Наук б-ка; НАН України. Ін-т українознавства ім. Івана Крип'якевича; редкол.: І. Вакарчук, Я. Ісаєвич (співголови) та ін. - Львів: Вид. центр ЛНУ ім. Івана Франка, 2006. $564 \mathrm{c}$.

16. Франко І. Еміль Золя. Життєпис [Електронний ресурс] / Іван Франко. - Режим доступу : http://www.i-franko.name/uk/BioStudies/1881/EmilZola.html. - Дата доступу: 14.01.2018.

17. Франко I. Нариси історії українсько-руської лїтератури до 1890 р. / Переднє слово I. Франка. - У Львові: Накладом Українсько-Руської Видавничої Спілки, 1910, V, 444 с.: портр. - (Писаня Івана Франка; [Т.] 1; Лїтературно-Наукова Біблїотека. Серія 1; Чис. 116).

18. Франко I. Передне слово від видавництва «Дрібної бібліотеки» [Електронний ресурс] / Іван Франко. - Режим доступу : http://www.i-franko.name/uk/Misc/1879/ PerednjeSlovoVidVydavn.html. - Дата доступу: 12.01.2018.

19. Франко I. Роман Е. Золя «L’assommoir» [Електронний ресурс] / Іван Франко. - Режим доступу : http://www.i-franko.name/uk/LitCriticism/1877/RomanEZoljaLassommoir.html. Дата доступу: 28.12.2017.

20. Франко I. Curriculum vitae (1890) [Електронний ресурс] / Іван Франко. - Режим доступу : http://www.i-franko.name/uk/Biography/CurriculumVitae1890.html. - Дата доступу: 2.01.2018.

21. Якилович Б. Іван Франко - видавець: книгознавчі та джерелознавчі аспекти / Богдан Якимович; ЛНУ ім. Івана Франка. - Львів: Вид. центр ЛНУ ім. Івана Франка, 2006. - 691 с.: портр., іл.

22. Якилович Б. Книга, просвіта, нація / Богдан Якимович; НАН України. Ін-т українознавства ім. І. Крип’якевича; Т-во «Просвіта». - Львів, 1996. - 308 с.

23. Ярелко Я. Лінгвополітологічний дискурс Івана Франка і сучасна теорія комунікації [Електронний ресурс] / Ярослав Яремко // Проблеми гуманітарних наук: зб. наук. праць Дрогобицького державного педагогічного університету імені Івана Франка. Серія філологія / Дрогобицький державний педагогічний університет імені Івана Франка; гол. ред. М. Федурко. - Дрогобич: Редакційно-видавничий відділ ДдПУ імені Івана Франка, 2016. - № 38. - С. 4-11. - Режим доступу : http://ddpu.drohobych.net/filol_gum/wp-content/ uploads/2016/04/2016-03.pdf. - Дата доступу: 12.02.2018. 
УДК 655.4 (477.83-25) «1877-1880» (082.1) (092) Іван Франко

\section{«ДРІБНА БІБЛІОТЕКА» І. ФРАНКА (1877-1880): ПРИКЛАД УСПІШНОї

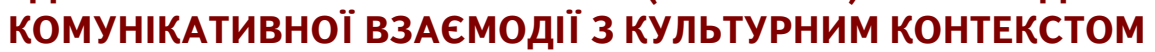

Сирота Лілія, канд. філол. наук,

Львівський національний університет імені Івана Франка, вул. Валова, 18, Львів, 79008, Україна, e-mail: liljasyrota@yahoo.com.

ORCID - https://orcid.org/0000-0001-7237-291X.

Вступ. Остання третина XIX ст. - час піднесення української культури в Галичині та громадської активності її представників. Спостерігаємо вагомі досягнення української інтелігенції у видавничій сфері. І. Франко, М. Павлик, І. Белей піклувалися про освіту народу, видаючи упродовж 1877-1880 pp. книжкову серію «Дрібна бібліотека» .

Актуальність. На сьогодні майже не існує «білих плям» у вивченні життя і діяльності I. Франка та його однодумців, однак деякі факти потребують уточнення і деталізації.

Мета статті. На основі аналізу листування I. Франка з М. Драгомановим, М. Павликом, О. Рошкевич акцентувати увагу на хронологічних межах участі цих діячів у виданні книжкової серії "Дрібна бібліотека», показати складні суспільні та фінансові умови, в яких довелося готувати до друку томи цієї серії, розкрити причини припинення праці над нею тощо.

Методологія. Автор спиралася на досягнення Б. Якимовича, М. Тимошика, О. Дея та ін., у яких широко представлено видавничу діяльність I. Франка в контексті його часу. Використано хронологічний, зіставний, психологічний методи, а також аналізу та логічного групування джерельного матеріалу.

Результати дослідження. Завдяки I. Франкові галичани мали змогу читати українською мовою найновіші резонансні художні твори й наукові розвідки відомих у Свропі авторів. Видаючи «Дрібну бібліотеку», він листувався з діячами на провінції і в еміграції, запрошуючи їх до праці над перекладами, шукаючи кошти для друку. Надіявся, що видані книги сприятимуть духовному росту українців, прагнув до тематичного розширення серії. Листування дозволяє відчути літературну атмосферу останньої третини XIX ст. як Західної Свропи, так і Галичини, увійти в світ модерних філософсько-естетичних ідей та природознавчих відкриттів, якими жили тоді люди. I. Франко одним із перших знайомив українців зі здобутками світової художньої літератури та науки; регулярно слідкував за книжковими новинками у Росії, Польщі, Німеччині, Франції; підтримував малознаних перекладачів, заохочуючи їх до праці, зокрема допоміг «вийти в люди» О. Рошкевич, друкуючи її переклади.

Висновки. І. Франко - менеджер, редактор, видавець, популяризатор «Дрібної бібліотеки». Можна сміливо ствердити, що ця серія - Франкова. Результати дослідження ії тематико-типологічних особливостей, видавничі контакти I. Франка, ставлення української інтелігенції до його задумів можуть бути використані у більш ширших наукових дослідженнях із проблем типології книги XIX ст., суспільної активності, книжкового репертуару видавничих осередків тощо.

Ключові слова: Іван Франко, книжкова серія "Дрібна бібліотека», епістолярна спадщина, телатика, переклад, фінансування, 1877-1880.

Стаття надійшла до редакції 21.02.2018. 